\title{
The Factors of Constitutional Support for the Rule of Law in the System of Public Authorities
}

\author{
MYKOLA M. STADNYK \\ Department of Public Policy and Political Analytics, National Academy for Public Administration under \\ the President of Ukraine \\ 3A Zarichna Street, 02132, Kyiv \\ UKRAINE \\ SERHII B. CHEKHOVYCH \\ Legal Policy Directorate, Office of the President of Ukraine \\ 11 Bankova Street, 01220, Kyiv \\ UKRAINE \\ HANNA S. YERMAKOVA \\ Institute of Legislation of the Verkhovna Rada of Ukraine \\ 4 Nestorivsky Lane, 04053, Kyiv \\ UKRAINE \\ and \\ Private Joint-Stock Company "Higher Education Institution ”Interregional Academy of Personnel \\ Management" ", \\ 2 Frometivska Street, 03039, Kyiv \\ UKRAINE \\ VALERIY V. KOLYUKH \\ Department of Political Sciences, Faculty of Philosophy, Taras Shevchenko National University of Kyiv \\ 60 Volodymyrska Street, 01033, Kyiv \\ UKRAINE \\ ILKIN S. NURULLAIEV \\ Department of International Law and Comparative Law, Faculty of International Relations, National \\ Aviation University \\ 1 Liubomyra Huzara Avenue, 03058, Kyiv \\ UKRAINE
}

\begin{abstract}
The article examines the factors that ensure the constitutional provision of the rule of law in the system of public authorities. The aim of this study was to analyse the factors that ensure the constitutional provision of the rule of law in the system of public authorities. The constitutional design provides for the creation of rational structures for the functioning of public authorities, which should ensure democratic standards, economic development, anti-corruption policy by implementing the principles of the rule of law. The study used data on indicators that describe the state of the rule of law (Rule of Law Index), democracy (Democracy Index) and corruption (Corruption Perceptions Index). Methods of graphical comparison, scattering diagrams, classification of countries by categories were used. A graphical model of the dependence of the rule of law on the development of democracy and perceptions of corruption for 25 European countries is built on the basis of these factors. It is proved that the studied indicators are dependent: countries with a high Rule of Law Index (high level of restrictions on the powers of government institutions, protection of fundamental rights, law enforcement, security) have a high
\end{abstract}


Corruption Perceptions Index (high level of anti-corruption) and Democracy Index. It is concluded that it is necessary to develop the constitutional provision of the rule of law by strengthening democratic values, improving economic growth and competitiveness, increasing control over corruption. Further research should analyse the impact of rule of law factors in low- and middle-income countries.

Key-Words: Rule of Law, Public Administration, Democracy, Constitutional design, Corruption Perceptions Index.

Received: May 17, 2021. Revised: November 7, 2021. Accepted: December 17, 2021. Published: January 13, 2022.

\section{Introduction}

The Constitution as the basic law forms certain limits that should regulate social relations. The core of these relations are issues related to economic and political organisation; establishment and functioning of government institutions and the relationship between the citizen and the state. Based on the functions of the Constitution, the main directions of its organising influence are the economic, political and social spheres of public relations. The Constitution plays a key role in the formation of a democratic, legal state with the establishment of the rule of law, the priority of human rights and freedoms. Voting rights affect the openness of the electoral process, political restrictions, and the freedom of establishing parties. In addition to the right to vote, there are broad electoral rules related to the quality of political and socio-economic institutions: accountability and representation. Accountability allows voters to identify decisionmakers and policy makers. It is believed that greater representation generates policies that benefit the general population and increase public goods [1].

The rule of law, human rights and democracy are European values that define the concept "constitutional democracy". The rule of law has become a central task of strategies in the field of state-building, conflict resolution and economic development. Modern constitutional systems have a wide variety of models that use party systems, governance structures, consensus democracy, and opposition activities. Democratic constitutions limit the powers of public authorities and protect fundamental human rights, which generally shape a free and open society. This is mainly realised through the creation of elected and representative institutions of governance, guaranteeing human rights (demonstration of one's views, freedom of assembly, right to confidentiality, property rights, freedom of movement, upholding the right to a fair trial) [2]. According to [3] the rule of law is important for economic development, justice, conflict, crime and violence prevention and containment, increasing accountability, reducing corruption, strengthening the equitable distribution of services. The main aspect of constitutions that affects political and socioeconomic institutions relates to the form of government, in particular the distinction between parliamentary and presidential regimes. It is believed that presidential regimes show more responsibility because they single-handedly concentrate executive powers, reporting directly to voters. Parliamentary democracy is less accountable because policy outcomes are not embodied with specific decisionmakers, given the parliamentary nature of the negotiations. Personal rights enshrined in constitutions can form political institutions through political competition and participation in elections. Discussion of existing theories identifies broad categories of constitutional variables that should influence political and socio-economic institutions: electoral rules, the system of checks and balances, the rule of law and human rights [1].

The concept "separation of powers" is defined as a state system which involves three branches of government, being in balance defined by law and provided with legal regulations, with the right to control the compliance with the law. The rule of law is becoming the centre of a modern democratic system in which none of the powers of the state has precedence and in which each form of government balances the other [4]. By ensuring the rule of law, the main tasks in the system of public administration aimed at political and socio-economic development are implemented, and corruption is curbed.

The constitution is based on a modern institutional design with a certain distribution of power between different political institutions. The emergence of constitutions as a key element in the transition from autocracy to democracy has increased the spread of various institutional decisions regarding the separation of powers. As this spread leads to the 
creation of unique constitutional hybrids, it is important to understand the degree of internal coherence of constitutional provisions. Institutions that balance each other through checks and balances are necessary for the development of democracy. These results have significant implications for institutional design and the issue of the best institutional solution in democratic consolidation [5]. Based on the above, the key issue is the implementation of the principles of the rule of law in the system of interaction of public authorities, which provide democratic institutions and exercise control over corruption. So, the main purpose of this study is to analyse the formation of factors of constitutional support for the rule of law in the system of public authorities. The main objective of the study is to identify key factors related to the rule of law and to determine the impact of individual factors on strengthening the rule of law as a key basis for the functioning of the public administration system.

\section{Methodology}

The methodology and practical approach of the work uses the available data on the indicators of the rule of law, democracy and corruption perception in 2020 [6-8]. The study is based on selected results from previous studies [9]. The research by [1] proves the connection between the constitutional construction of electoral systems and the guarantee of human rights with the rule of law. Other researchers confirm possible relationships between the rule of law, anticorruption policy and democratic institutions [10]. Using this approach, we proposed our own characteristics of the rule of law, democracy and corruption perception. The next step was to determine the relationship between these indicators. Informational and analytical sources were used as an empirical basis, which contain processed data on the peculiarities of the modern processes for the establishment of the rule of law, development of democracy and anti-corruption activities. The study used some approaches used in the correlation analysis of data [11-12]. The Rule of Law Index assesses the rule of law through several indicators. Restrictions on powers and transparency of government institutions, absence of corruption, protection of rights, order and security, observance of laws, and justice are determined. The Rule of Law Index is the main source of independent data on the rule of law. The Index is designed to promote political reforms, development programmes, and inform researchers to strengthen the rule of law [8]. In order to determine the perception of public sector corruption in different countries around the world, the Corruption Perceptions Index was used [13]. The last factor used is the Democracy Index developed by [6], which is a well-known indicator of the state of democracy in the country. The Democracy Index determines the democratic manifestations based on the following categories: civil liberties; electoral process and pluralism; functioning of the government; political participation; political culture. Based on the available data on the Rule of Law Index for individual European countries, existing empirical studies on democracy and corruption, the study is based on an assessment of the impact of these predictors on the rule of law. Based on the obtained data, graphical models of ensuring the rule of law and the changes that took place in 2015-2020, as well as the dependence of the rule of law on democracy and the corruption perception index for 25 European countries, which will allow identify the degree of influence of certain factors on the constitutional formation of the rule of law.

\section{Results}

The task of the Constitutions is to mitigate the influence of government in different ways, through different orders in society, institutional separation, multi-party systems and the role of the opposition. The need to express different public views through constitutions, the embodiment of ideas and interests through institutionalised, open and representative political processes has positive consequences. This is determined by the rational formation of governments by political coalitions, which must ensure sustainable economic development and a decent standard of living. Analysis of the relationship of the rule of law with the high economic level of the country shows certain trends. Figure 1 shows the values of the Rule of Law Index in 2020 of 25 European countries covered in the study and the level of GDP per capita. As the above data shows, we can talk about a certain trend: countries with a higher level of GDP per capita mostly have a higher Rule of Law Index. Tracking the progress of European states in building the various components of the rule of law, it can be noted that positive changes have not taken place in all countries. The chart (Figure 2) classifies European 
countries taking into account the increase or decrease in their assessments of the rule of law in 2020 and the results of the indicator compared to 2015 (increase, stable value, decrease).

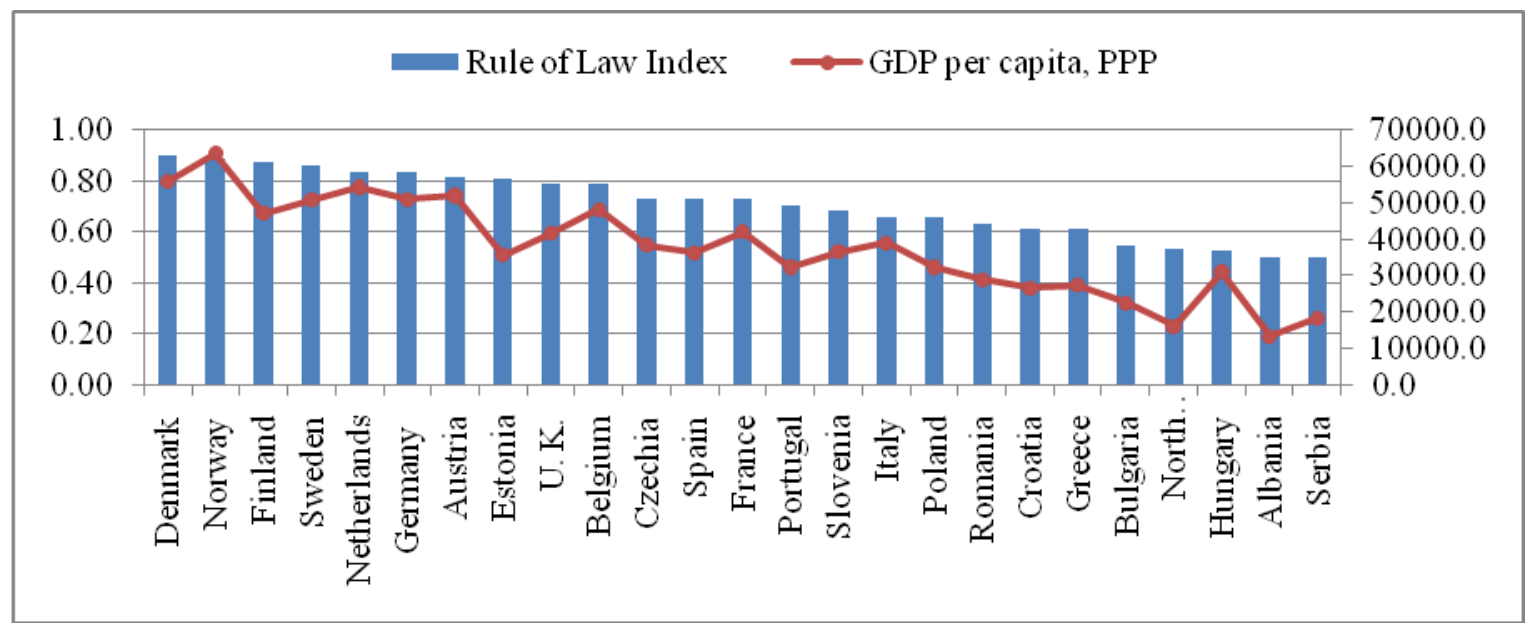

Fig. 1: Rule of law index and GDP per capita, $2020[8,14]$

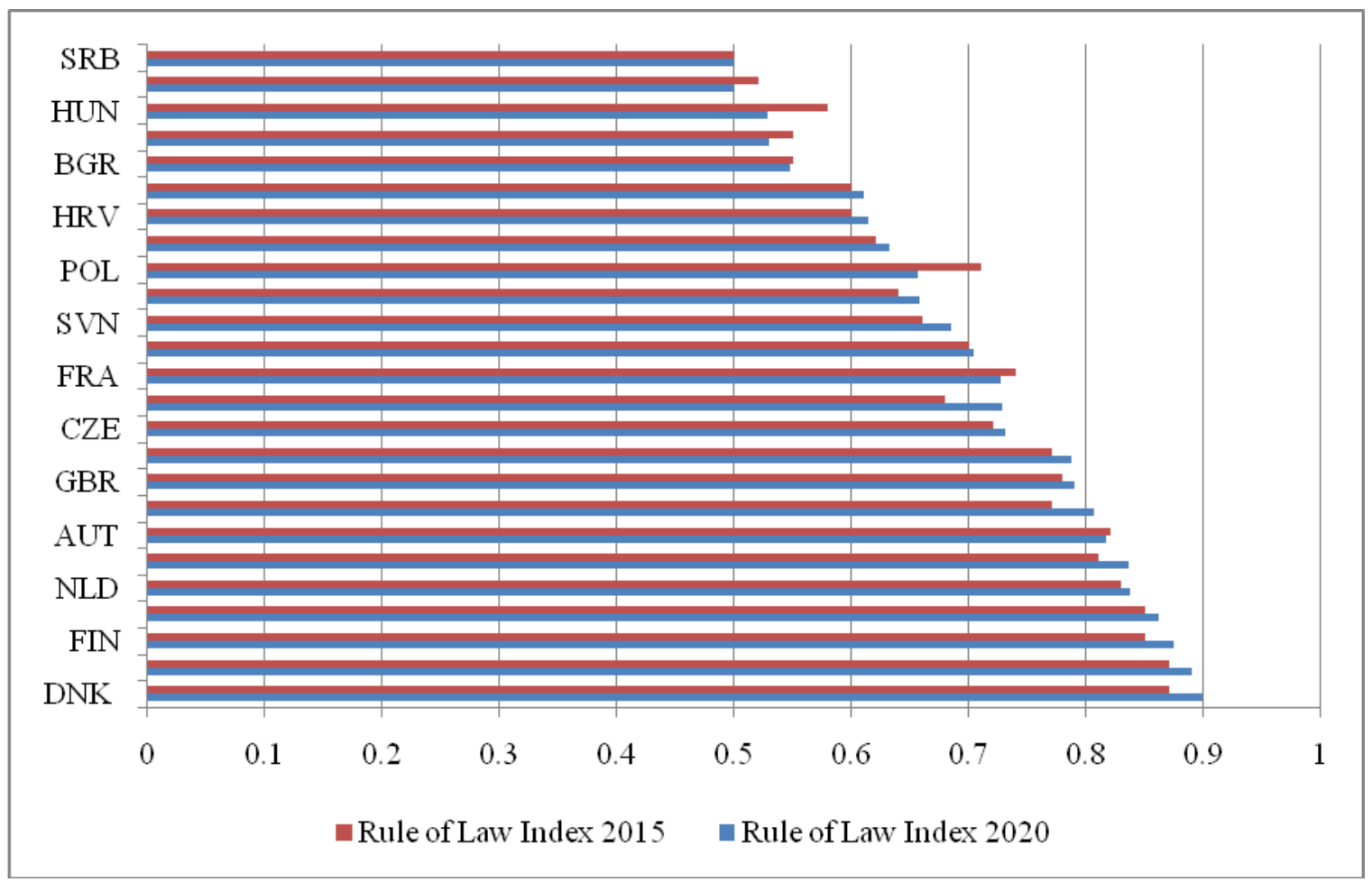

Fig. 2: Ensuring the rule of law and the changes that took place in 2015-2020 [8, 15]

The most negative results should be noted. Indicators of the rule of law of Hungary for 5 years decreased in the areas of: limitation of powers of government institutions (-0.09), protection of fundamental rights $(-0.08)$, civil and criminal justice $(-0.08)$. Poland reduced its indicators in the areas of: limitation of powers of government institutions (-
$0.19)$, protection of fundamental rights $(-0.13)$, criminal justice $(-0.14)$. Over the last decade, the growth of electoral autocracy has been largely the result of the gradual disintegration of democracies. From 2018 to 2019, Hungary began to be classified as an authoritarian regime, which is a significant example of democratic regression in recent times. 
Hungary was classified as a liberal democracy in 2009 , but in 2014 the rate of freedom and fairness of elections declined, and the media, civil society and civil liberties became significantly limited. Similarly, Poland has deepened its autocratic position over the past 10 years. The events in Poland testify to the gradual elimination of media freedom and the collapse of civil society, given the laws on the media in 2015-2016.

The concept of democracy includes various elements: competition in elections, constitutionalism, discussion and political equality. Democratic norms in society should be accompanied by increased freedom of speech and the press, which publishes information about participation in political life and competition in the election race. European countries surveyed in terms of democracy development on the basis of the Democracy Index have different indicators: from 5.89 (Northern Macedonia) to 9.81 (Norway). The relationship between the Rule of Law Index and the European Democracy Index is shown in Figure 3. The scatter chart proves the relationship between the Rule of Law Index and the Democracy Index. The scatter plot shows that there is a linear relationship with a positive correlation, ie an increase in the value of the Democracy Index corresponds to an increase in the value of the Rule of Law Index. The quality of the model according to the coefficient of determination $\left(\mathrm{R}^{2}\right)$ is 0.872 , which is an acceptable level. There are countries with the highest level of democratic environment and the highest indicators of the rule of law.

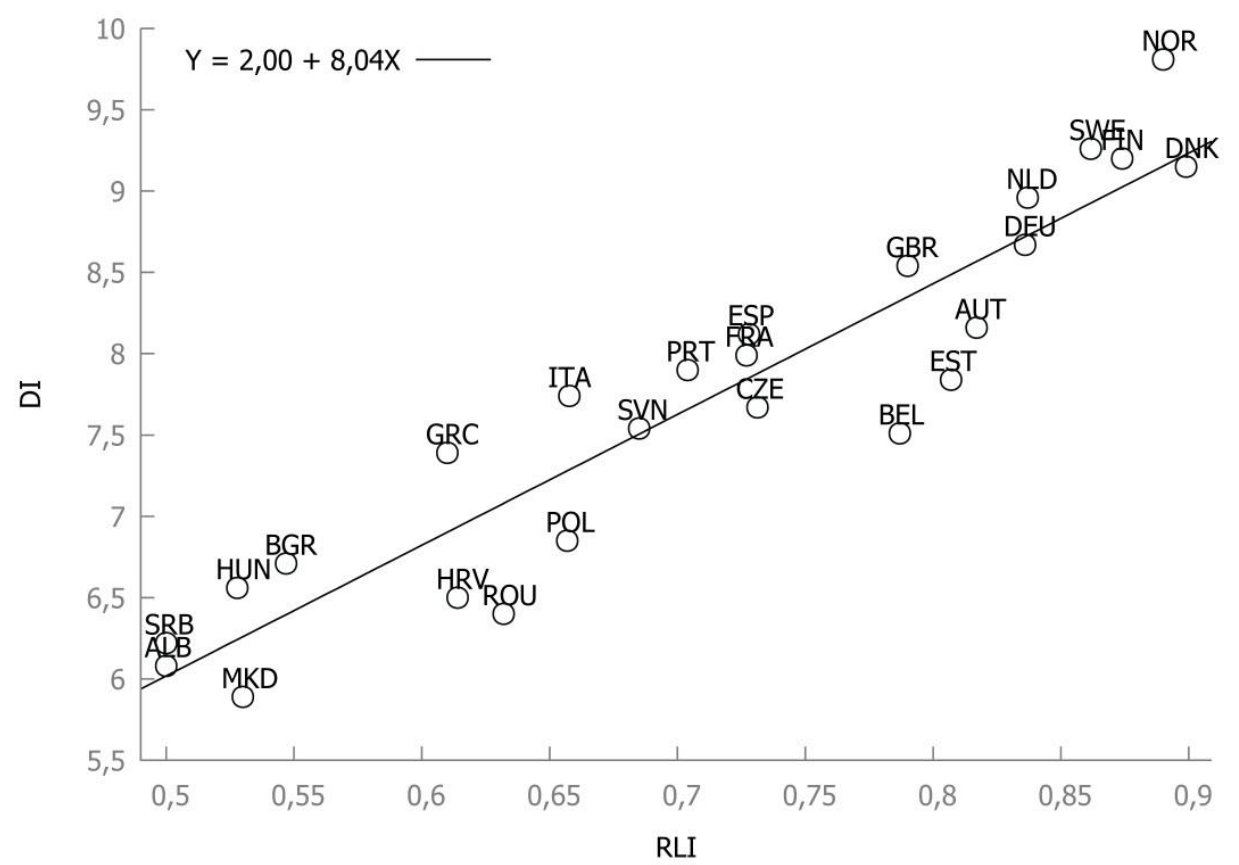

Fig. 3: The relationship between the Rule of Law Index and the Democracy Index $[6,8]$

Another approach was to determine the perception of the level of corruption in the public sector. The methodological approach was based on the use of the Corruption Perceptions Index as an indicator of corruption control. This index quite objectively determines the anti-corruption policy in the country. In this case, assessments of the following issues are used: bribery, misuse of budget funds, state opportunities to curb corruption, mechanisms of criminal liability for corruption, disclosure of financial information. European countries surveyed in terms of the Corruption Perceptions Index vary from 35 in Northern Macedonia to 88 in Denmark.
The relationship between the Rule of Law Index and the Corruption Perceptions Index in Europe is shown in Figure 4. The scatter chart shows the relationship between the Rule of Law Index and the Corruption Perceptions Index. The scatter plot shows that there is a linear relationship with a positive correlation, ie an increase in the value of the Corruption Perceptions Index corresponds to an increase in the value of the Rule of Law Index. The quality of the model according to the coefficient of determination $\left(\mathrm{R}^{2}\right)$ is 0.952 , which is an acceptable level. There are countries with the highest level of anti-corruption 
environment and the highest indicators of the rule of law.

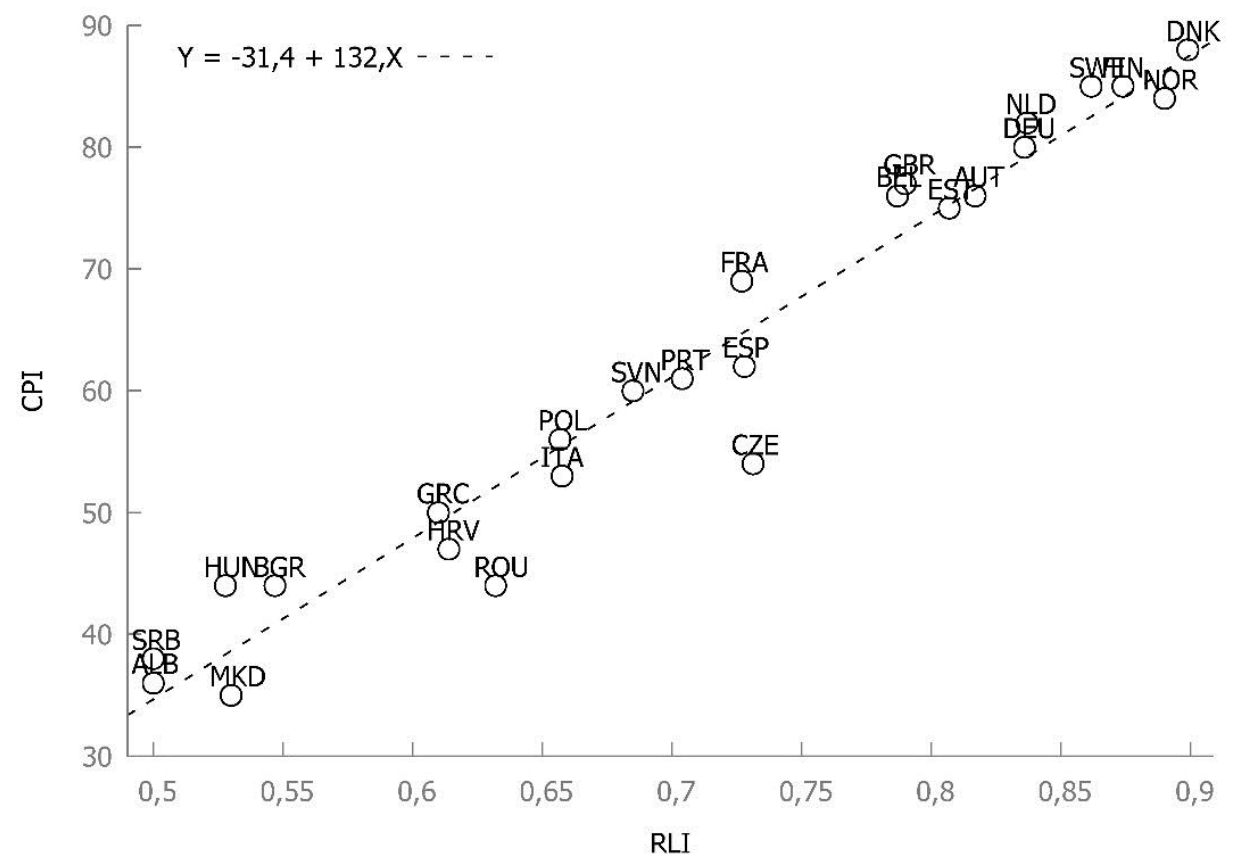

Fig. 4: The relationship between the Rule of Law Index and the Corruption Perceptions Index $[8,13]$

Corruption also affects democratic rights and the rule of law. Some approaches to tackling corruption could be to improve the quality of education, increase women's participation in public administration, delegation, freedom of the press and the rule of law. It is important to find out the influence of the peculiarities of the constitutional separation of powers on the rule of law. If we analyse the forms of government in Europe on the basis of data [16] we can note the following: the vast majority of countries with the highest level of rule of law are parliamentary constitutional monarchies. This suggests that the constitutionally defined form of separation of powers, where the executive branch is headed by a prime minister.

\section{Discussion}

The results prove that the rule of law is one of the foundations for ensuring the development of countries with a high standard of living. Moreover, it can be noted that strengthening the rule of law is one of the effective elements of economic development, which ensure the competitiveness of the state and shape the quality of life. This confirms the conclusions of scholars that the needs of the comprehensive development of society and the citizen, the constitutional provisions, provide effective global rules. These approaches encourage the state to finance, control and implement poverty reduction policies [17]. Another study demonstrates a direct empirical relationship between the rule of law and key economic indicators [1]. Effective rule of law reduces poverty, strengthens the social protection system, and is the foundation of justice, opportunity and peacekeeping, accountable government and respect for fundamental rights for communities [8].

Analysis of the factors that ensure the rule of law on the basis of strengthening democratic values and expanding anti-corruption activities, proves the importance of these factors in strengthening the rule of law in European countries. Despite significant efforts to ensure governance through the rule of law, there is a mismatch between expectations from political declarations and actual results [18]. Some researchers [19] argue that the ineffectiveness of rule of law reforms may stem from a mismatch between the legal aspects of governance and the social norms that govern citizens and officials; that is, ignoring system effects.

The limitation of the study is the coverage of only certain European countries, mostly with a high level of development. Besides, the results contain available data for 2020 and 2015. For a more complete 
analysis, it is advisable to involve more countries with different levels of economic development. There is one more issue of the methodological approach to the use of an expanded set of indicators that shape the factors of the rule of law. Some studies claim that the level of corruption is lower in more affluent countries than in poorer countries [7], which is reflected in the results. Combined with higher economic growth, wealthy countries tend to have strong legal, institutional, and educational mechanisms to reduce corruption. The findings point to clear reform priorities, as stronger democratic institutions and the rule of law improve control over corruption. Evidence suggests the need for freedom of expression, improved regulation and a stable political climate to further strengthen the capacity of political institutions to control corruption. Strengthening political institutions can reduce corruption by creating favourable conditions for sustainable economic development [10].

Improving the efficiency of public authorities and ensuring positive changes in the institutional environment is possible by intensifying anticorruption activities [20]. Corruption influence creates negative consequences in the system of public authorities; narrows the constitutional rights and freedoms of citizens; violates the principles of the rule of law; inhibits and distorts political and socioeconomic reforms [21]. Research mainly shows that corruption increases the misallocation of economic resources, reduces economic growth, slows down productivity and increases income inequality [22].

The theory of political competition states that the strength of democratic institutions is closely linked to the ability to control corruption. In strong democracies, political competition (elections, citizens' own rights and freedom of the press) improves transparency. This ensures that public authorities are responsible for making decisions. The rule of law is associated with higher control of corruption, other things being equal [10].

In the study of the links between the strength of democratic institutions and the control of corruption; between government efficiency and control of corruption, as well as between legal institutions and control of corruption, high-quality state and political institutions are important and positively associated with a strong anti-corruption policy. Freedom of the press strengthens the link between the government and the political institutions that control corruption. This conclusion confirms the assumption [23] that the introduction of freedom of the press should be accompanied by information on the detection of fraud and corruption. The quality of regulation and political stability significantly enhances the ability of government and political institutions to control corruption [10].

The authors of [24] identify their own determinants of the anti-corruption environment with direct policy tools: education, freedom of trade, rule of law, political rights. The quality of government and political institutions is positively related to efficiency and public development, determining control over corruption [10]. Based on the meaning of the rule of law, the key factors may be democratic principles (openness of society, respect for rights) and the absence of corruption [25]. Another model covers the systemic features of corruption in most countries: adaptive government, which sets budget priorities (resource allocation) in several decisionmaking bodies; civil servants who decide on the use of resources, and a network of externalities among policy issues (e.g., health, education, infrastructure, public administration, etc.) [18].

Democracy in the modern world is seen as a system of state organisation in which the rule of law is ensured by concrete means, and all aspects of political and social life are dictated by the rule of the majority through legal institutions [4]. Another study of the factors of democracy focuses on general indicators of democracy: the level of freedom, the combination of political rights and civil liberties, as measured by the V-Dem Liberal Democracy Index [26]. The approach used (horizontal accountability V-Dem) specifically aims to demonstrate the element of prevention of abuse of power, which changes the relationship between the president, parliament and government [5]. According to some data, the link between economic development and democracy is observed only in relation to the electoral component of democracy (the competitive national elections and the procedural integrity of the electoral process) [9].

Research shows that in countries with a higher quality of democracy, the state refrains from taking measures that are potentially contrary to democratic principles. Political institutions limit policy choices in times of crisis: previous decisions about models of political institutions reduce the decision-making space for political actors. Countries that develop personal freedoms continue to do so even in emergencies [27]. 
It should be noted that the indicators used in this study (Corruption Perceptions Index, Democracy Index) confirm the theses of the above scholars about the level of rule of law depends on the general state of democracy in the country and the effectiveness of anti-corruption policy. The indicators used in the study (as a characteristic of the factors ensuring the rule of law) proved the correctness of the methodology on the example of 25 developed European countries. The proposed approaches may describe the need to ensure the rule of law by public authorities, developing democracy, strengthening control over corruption and improving the quality of life. The analysis of the influence of factors was carried out separately for each area. Further research needs to use more predictors that influence the rule of law (gender gap, human development index, competitiveness index), and develop a methodology that takes into account the impact of political and socio-economic institutions on the rule of law.

\section{Conclusion}

Thus, modern models of the constitutional organisation of the system of public authorities provide for the functioning of high-quality political and socio-economic institutions. These institutions are aimed at establishing the rule of law, democratic foundations of public policy and guaranteeing human rights. A study of individual European countries has identified the impact of the level of democracy and the level of corruption perception on the rule of law. The consequences of a high level of the rule of law are significant economic growth, increased competitiveness of the country, social justice and increased confidence in government institutions. Unfortunately, not all processes of ensuring the rule of law strengthen the positions. The experience of European countries in recent years proves the possibility of regression in ensuring the rule of law through the introduction of certain undemocratic legislative provisions. In the context of the research topic, it is proved that the development of the rule of law involves the factors that allow the introduction of democracy in the state and strengthening anticorruption activities. Democratic values allow maintaining political culture, ensuring civil liberties and political participation, and exercising the right to electoral process and pluralism. Anti-corruption activities are based on public awareness, civic control, accountability and openness. It is determined that the constitutional distribution of powers of public authorities with a strong executive branch headed by the Prime Minister ensures a significant level of the rule of law. The study proves that the combination of the constitutional provision of certain models of power, the development of democratic values and anti-corruption principles of political and socio-economic institutions allow achieving high levels of the rule of law. Further research should focus on determining the impact of factors that form the rule of law in low- and middle-income countries.

\section{References:}

[1] Eicher, T. S., García-Peñalosa, C., Kuenzel, D. J., Constitutional Rules as Determinants of social Infrastructure, Journal of Macroeconomics, Vol. 57, 2018 pp. 182-209.

[2] Bisarya, S., Bulmer, W., Rule of law, democracy and human rights: the paramountcy of moderation, In M. Adams, A. Meuwese, E. Ballin (Eds.), Constitutionalism and the Rule of Law: Bridging Idealism and Realism, pp. 123158, Cambridge University Press, 2017.

[3] United Nations Development Program, Overview on the Rule of Law and Sustainable Development for the Global Dialogue on Rule of Law and the Post-2015 Development Agenda, 2013.

https://www.undp.org/content/dam/undp/library/ Democratic\%20Governance/Access\%20to\%20J ustice\%20and\%20Rule\%20of\%20Law/Concept $\% 20$ Note $\% 20$ -

\%20Global\%20Dialogue\%20on\%20RoL\%20an d\%20Post-2015.pdf

[4] Dinescu, A. G. Perspectives on the Rule of Law in a Modern Democracy, Lex ET Scientia International Journal, Vol. 25, No. 1, 2018, pp. 31-38.

[5] Fruhstorfer, A., Consistency in Constitutional Design and Its Effect on Democracy. Democratization, Vol. 26, No. 6, 2019, pp. 1028-1046.

[6] Economist Intelligence Unit, Democracy Index, 2020. https://www.eiu.com/topic/democracyindex

[7] Transparency International, Americas: Weakening Democracy and Rise in Populism Hinder Anti-Corruption Efforts, 2019. https://www.transparency.org/en/news/cpi2018-regional-analysis-americas 
[8] World Justice Project, Rule of Law Index 2020, 2020.

https://worldjusticeproject.org/sites/default/files/ documents/WJP-ROLI-2020-Online_0.pdf

[9] Knutsen, C. H., Gerring, J., Skaaning, S. E., Teorell, J., Maguire, M., Coppedge, M., Lindberg, S. I., Economic Development and Democracy: An Electoral Connection, European Journal of Political Research, Vol. 58, No. 1, 2019, pp. 292-314.

[10] Chong, S. P. C., Tee, C. M., Cheng, S. V., Political Institutions and the Control of Corruption: A Cross-Country Evidence, Journal of Financial Crime, Vol. 28, No. 1, 2020, pp. $25-48$.

[11] Schober, P., Boer, C., \& Schwarte, L. A. (2018). Correlation Coefficients: Appropriate Use and Interpretation. Anesthesia and analgesia, 126(5), pp. 1763-1768.

[12] Curtis, E. A., Comiskey, C., \& Dempsey, O. (2016). Importance and use of correlational research. Nurse Researcher, 23(6), pp. 20-25.

[13] Transparency International, Corruption Perceptions Index 2020, 2021. from http://www.transparency.org/cpi

[14] The World Bank, GDP Per Capita, PPP (Constant 2017 International \$), 2020. https://data.worldbank.org/indicator/NY.GDP.P CAP.PP.KD?end $=2016 \&$ start $=2010 \&$ view $=$ char t\&year_high_desc $=$ true

[15] World Justice Project. Rule of Law Index 2015, 2015. https://worldjusticeproject.org/sites/default/files/ documents/roli_2015_0.pdf

[16] Central Intelligence Agency, The World Factbook, 2021. https://www.cia.gov/the-worldfactbook/

[17] Minkler, L., Prakash, N. The Role of Constitutions on poverty: A Cross-National Investigation, Journal of Comparative Economics, Vol. 45, No. 3, 2017, pp. 563-581.

[18] Guerrero, O. A., Castañeda, G. Does Expenditure in Public Governance Guarantee Less Corruption? Non-Linearities and Complementarities of the Rule of Law, Economics of Governance, Vol. 22, No. 2, 2021, pp. 139-164.

[19] Baez-Camargo, C., Passas, N. Hidden agendas, Social Norms and Why We Need To Re-Think Anti-Corruption. Working Paper. Basel Institute on Governance, 2017.
[20] Xie, J, Zhang, Y. Anti-Corruption, Government Intervention, and Corporate Cash Holdings: Evidence from China. Economic Systems, Vol. 44, No. 1, 2020, Art. 100745.

[21] Filipenko, T., Filipenko, A., Turner, N., Organizational fundamentals for preventing corruption in local self-government bodies. In L. Popova, M. Petrova (Eds.), Professional Competencies and Educational Innovations in the Knowledge Economy: Collective Monograph, pp. 486-497, Publishing House Access Press, 2020.

[22] Transparency International, Corruption Perceptions Index 2016: Vicious Circle of Corruption and Inequality Must Be Tackled, 2017.

https://www.transparency.org/en/press/corruptio n-perceptions-index-2016-vicious-circle-ofcorruption-and-inequali

[23] Vadlamannati, K. C., Cooray, A. Transparency Pays? Evaluating the Effects of the Freedom of Information Laws on Perceived Government Corruption, The Journal of Development Studies, Vol. 53, No. 1, 2017, pp. 116-137.

[24] Jetter, M., Parmeter, C. F. Sorting through Global Corruption Determinants: Institutions and Education Matter-Not Culture. World Development, 109, 2018, pp. 279-294.

[25] Lane, J. E. Development is Rule of Law, International Journal of Social Science and Economics, Vol. 1, No. 1, 2021, pp. 62-70.

[26] Coppedge, M., Gerring, J., Lindberg, S. I., Skaaning, S.-E., Teorell, J., Altman, D. et al., $V$ Dem dataset V7.1. Varieties of Democracy Project, Gothenburg University, 2017.

[27] Engler, S., Brunner, P., Loviat, R., Abou-Chadi, T., Leemann, L., Glaser, A. et al, Democracy in Times of the Pandemic: Explaining The Variation of COVID-19 Policies Across European Democracies, West European Politics, Vol. 44, No. 5-6, 2021, pp. 1077-1102.

Contribution of Individual Authors to the Creation of a Scientific Article (Ghostwriting Policy)

All Authors contributed equally to the creation of the given scientific article

\section{Creative Commons Attribution License 4.0 (Attribution 4.0 International, CC BY 4.0)}

This article is published under the terms of the Creative Commons Attribution License 4.0 https://creativecommons.org/licenses/by/4.0/deed.en $\underline{\mathrm{US}}$ 